\title{
The notion of 'Nature conservation body' in Polish Nature conservation law, its types and competences
}

\section{Pojęcie „organu ochrony przyrody” w polskim prawie ochrony przyrody, ich rodzaje i kompetencje}

\begin{abstract}
The aim of the article is the review of currently binding legal solutions concerning the organization of nature conservation administrative bodies in Poland. The task of nature conservation in Poland is accomplished by a great number of entities, which vary in the scope of their status, rules of action and given competences. The review of legal solutions in the article has been limited to the structure of 'nature conservation body' as defined by the Polish nature conservation law. The analysis of legal state de lege lata in this matter will allow to formulate assessments concerning
\end{abstract}

Doctor of Laws, Assistant Professor at the Chair of Environmental Protection Law, Faculty of Law and Administration, Nicolaus Copernicus University in Torun. 


\section{Karolina Karpus}

the correctness of legal principles. The main criterion of conducted assessment will be the efficiency of nature conservation bodies in providing the right level of nature conservation in Poland.

Key words: Nature conservation law; nature conservation body; competences

\section{Streszczenie}

Celem opracowania jest przegląd obecnie obowiązujących rozwiązań prawnych dotyczących organizacji aparatu administracji ochrony przyrody w Polsce. Zadanie, jakim jest ochrona przyrody wykonywane jest w Polsce przez wielką grupę podmiotów, które cechuje olbrzymia różnorodność w zakresie ich statusu, zasad działania oraz przyznanych kompetencji. Przegląd rozwiązań prawnych ograniczony został w artykule do struktury, jaką jest „organ ochrony przyrody” w rozumieniu polskiego prawa ochrony przyrody. Analiza stanu prawnego de lege lata w tym przedmiocie pozwoli na sformułowanie ocen co do prawidłowości tych przepisów prawnych. Głównym kryterium przeprowadzanej oceny jest skuteczność organów ochrony przyrody w zapewnieniu właściwego poziomu ochrony przyrody w Polsce.

Słowa kluczowe: Prawo ochrony przyrody; organ ochrony przyrody; kompetencje

\section{Introduction}

The legislator attempts to define the environment in which a human being lives. Hence, the definition of 'environment' in the chief act for this part of law, i.e. the Act of 27 April 2001 on Environmental Protection Law ${ }^{1}$ (further referred to as the EPA). According to article 3 point 39 of the EPA, the 'environment' is 'the whole of environmental elements, including those transformed as a result of human actions, especially ground surface, fossils, water, air, landscape, climate and other elements of biological variety, as well as mutual influence between those elements'. Thus the content of this

1 Journal of Laws of 2013, item 1232 with amendments, consolidated text: further 
notion lists nature elements, which are colloquially understood (the Polish language dictionary defines the notion of 'nature' as 'earth, water and air along with plants and animals living on or in it').

In article 5 section 20 of the Act of 16 April 2004 on Nature Conservation $^{2}$, the legislator defined a narrower notion than the notion of 'environment' in the EPA, i.e. the notion of 'natural environment'. According to this principle 'natural environment' is 'landscape along with inanimate nature creations and natural or transformed natural habitats including plants, animals and mushrooms found on them'. By combining this notion with the notion of 'natural habitat' (which according to article 5 section 17 of the EPA is 'land or water area, natural, semi natural or anthropogenic, distinguished based on geographical, abiotic and biotic features') one may try to limit the boundaries of the legislator's interest in the case when the legislator refers to 'nature' or 'nature conservation'. The group of norms, whose regulation subject is this kind of environment and the relation of a human being to such environment, is defined as nature conservation law, which from the systematic point of view constitutes an internal section of environmental protection law.

The main normative act concerning nature conservation (apart from the EPA) is the Act of 2004 on Nature Conservation mentioned above ${ }^{3}$. However, by applying as a classification criterion the definition of 'natural environment', it should be pointed that a considerable group of nature conservation norms is included in other normative acts. As an example the following acts should be mentioned:

- the Act of 13 October 1995 on Hunting Law';

2 Journal of Laws of 2013, item 627 with amendments, consolidated text; further referred to as the NCA.

3 In regard to Nature conservation law and the organization of Nature conservation administration in Poland - see: M. Górski, Ochrona środowiska jako zadanie administracji publicznej, Łódź 1992; A. Przyborowska-Klimczak, Ochrona przyrody. Studium prawnomiędzynarodowe, Lublin 2004; Integralna ochrona przyrody, ed. M. Grzegorczyk, 2007; E. Symonides, Ochrona przyrody, Warszawa 2008; Instytucje prawa ochrony środowiska: geneza, rozwój, perspektywy, ed. W. Radecki, Warszawa 2010; Ochrona przyrody, ed. M. Gwiazdowicz, Studia BAS No 10, Warszawa 2008; Organizacja ochrony środowiska, ed. M. Rudnicki, Lublin 2011; Administracja publiczna a ochrona przyrody: zagadnienia ekonomiczne, spoteczne oraz prawne, ed. M. Górski, Warszawa-Stare Babice-Siedlce 2012; Ocena modelu prawnego organizacji ochrony środowiska w Polsce i na Stowacji: praca zbiorowa, ed. E. Ura, J. Stelmasiak, S. Pieprzny, Rzeszów 2012.

4 Journal of Laws of 2013, item 1226 with amendments, consolidated text. 


\section{Karolina Karpus}

- the Act of 3 October 2008 on Access to Information on Environment and its Protection, Public Participation in Environmental Protection and on Environmental Impact Assessment;

- the Act of 13 April 2007 on Environmental Damage Prevention and its Remediation ${ }^{6}$;

- the Act of 18 December 2003 on Plant Protection;

- the Act of 6 July 2001 on Preservation of the National Character of Strategic Natural Resources of the Country ${ }^{8}$;

- the Act of 22 June 2001 on Genetically Modified Organisms9;

- the Act of 21 August 1997 on Animal Protection ${ }^{10}$;

- the Act of 28 September 1991 on Forests ${ }^{11}$;

- the Act of 18 April 1985 on Inland Fishery ${ }^{12}$.

Thus, nature conservation law has dispersed nature. This circumstance constitutes an additional factor, which makes it difficult to determine the notion of 'nature conservation body'.

\section{The notion of 'nature conservation body'}

In the Act of 2004 on Nature Conservation, the legislator uses three notions: 'body in the scope of nature conservation', 'nature conservation services' and 'consultative-advisory bodies in the scope of nature conservation'.

According to article 91 of the NCA, the bodies in the scope of nature conservation are: the Minister competent for environmental matters, the General Director for Environmental Protection, the voivode, the regional director for environmental protection, the marshal of a voivodeship, the director of a national park, starost, wojt, town or city mayor. Whereas,

5 Journal of Laws of 2013, item 1235 with amendments, consolidated text; further referred to as the Act of 2008.

6 Journal of Laws of 2014, item 210 with amendments, consolidated text.

7 Journal of Laws of 2014 item 621 with amendments, consolidated text.

8 Journal of Laws of 2001, No 97, item 1051 with amendments.

9 Journal of Laws of 2007, No 36, item 233 with amendments, consolidated text.

10 Journal of Laws of 2013, item 856 with amendments, consolidated text.

11 Journal of Laws of 2011, No 12, item 59 with amendments, consolidated text; further referred to as the Act of Forests.

12 Journal of Laws of 2009, No 189, item 1471 with amendments, consolidated text. 
according to the contest of Chapter 6 of the NCA 'Nature conservation services' the legislator included here two structures: National Park Services (including National Park Guard - article 108 of the NCA) and Landscape Park Services. Among the 'consultative-advisory bodies in the scope of nature conservation' the legislator included, in article 95 of the NCA: the State Council for Nature Conservation at the Minister competent for environmental protection; the regional council for nature conservation at the regional director for environmental protection; the science council of national park at the director of national park; the council of landscape park or the council of a group of landscape parks at the director of landscape park or the director of a group of landscape parks.

The solution applied by the legislator in the EPA should also be remembered. It uses the following terms: 'environmental protection bodies' and 'environmental protection institutions' ${ }^{13}$. According to article 376 of the EPA, the first group includes: wojt, town or city mayor; starost; voivodeship sejmik; voivodeship marshal; voivode; the minister competent for environmental protection; the General Director for Environmental Protection; the regional director for environmental protection. According to article 386 of the EPA, the 'environmental protection institutions' are: the State Council for Environmental Protection, committees on environmental impact assessment, the National Fund for Environmental Protection and Water Management and voivodeship funds for environmental protection and water management.

On the grounds of the above mentioned solutions applied by the legislator the following base conclusion may be drawn that bodies are appointed applying the nominal method. At the same time, it would mean that catalogue of bodies included in the classification of both acts has overall and closed character with reference to 'environmental protection body' and 'nature conservation body'. However, the analysis of normative acts being the source of nature protection law, clearly speaks against such statement. The enumeration included in the catalogues, introduced by the legislator in both main acts, should be treated only as a model enumeration of bodies. Similarly, the distribution of some bodies in individual categories also seems to have such character.

13 See: A. Haładyj, M. Rudnicki, J. Trzewik, P. Zacharczuk, Podstawowe konwencje terminologiczne z organizacji ochrony środowiska, in: Organizacja ochrony środowiska, ed. M. Rudnicki, Lublin 2011, p. 27-30. 


\section{Karolina Karpus}

Thus, it is not fully possible to define clearly the right scope of 'nature conservation body' based on those provisions. While trying to define the scope, the terms 'environment' and 'natural environment' should be mentioned again. It may be accepted that in this case the second term is the criterion which allows to say that 'nature conservation body' is a public administration body having competence within 'landscape along with inanimate nature creations and natural and transformed natural habitats with plants, animals and mushrooms living on it'. Besides, it should be stated that 'nature conservation bodies' are always at the same time 'environmental protection bodies'. The second criterion of distinguishing 'nature conservation bodies' are three functions of environmental protection, as public administration tasks (see article 3 section 13 of the EPA) preventive (pollution prevention), conservative (rational environment development and environmental resources management in accordance with the sustainable development principle) and compensative (restoration of nature elements to their proper state). Bearing in mind that in fact each 'environmental protection body' accomplishes its tasks in accordance with those functions, it may be noticed that the legislator assigning tasks within environmental protection diversifies the level of each of the functions in reference to individual groups of bodies. In the case of 'nature conservation bodies' the most important is without doubt the conservative function, which is accompanied by the compensative function but most often on the background level.

To sum up, a 'nature conservation body' is a structure of public administration, which is personal being, is a distinguished organization, is authorised to act in the name of the state, is equipped with administrative authority and has competence within the task which is above all rational resource development and management, defined as 'natural environment'. 


\section{Kinds of nature conservation bodies and their competences}

\subsection{Introductory remarks}

The legislator developing the administrative structure of nature conservation in Poland applied a lot of structural solutions. Thus, as a result a variety of administrative entities competent in this scope may be pointed out. On one hand, historical traditions (among others the State Council for Nature Conservation) have a definite impact on this process. On the other hand, it is the principle of public authority decentralization, which is accomplished not only in the relation: government administration - selfgovernment administration, but also in the relation to entities outside public administration. An additional factor, which may be distinguished, having influence on the development of this administrative structure, is the need of close cooperation with research community and the conduct of scientific research, which is reflected in interdisciplinary nature of environmental protection law, including nature conservation law.

In this group of administrative entities besides bodies are also structures defined as 'services' and 'guards', or special organization solutions, such as: the State Forests National Forests Holding defined as 'state organization unit without legal entity', or the Polish Hunting Association, which is the 'association of private and legal entities'. One may also mention botanical gardens, zoos and animal rehabilitation centres, which should be classified as individual administrative units. The legislator used also such structures as state research institutes (e.g. the Institute of Environmental Protection), which on the grounds of special provisions gain the administrative authority in some areas. Sometimes, the legislator indicates a special official in an administrative body, as is the case of the Chief Nature Conservator at the Minister competent for environmental matters and a regional nature conservator at the regional director for environmental protection. The characteristic feature of administrative structure of nature conservation should also be mentioned. It is connected with two area forms of nature conservation - a national park and landscape park. Including chosen areas in this special legal regime is tantamount with establishing special administration for both kinds of parks. 


\section{Karolina Karpus}

The above mentioned variety of solutions applied by the legislator during the development of nature conservation administrative structure requires a separate and broader analysis ${ }^{14}$. For purposes of this article, it is necessary to limit the discussion to the group of administrative entities classified as 'nature conservation bodies', which fulfil the primary condition, i.e. unquestionable status of a classic public administrative body.

\subsection{The classification of nature conservation bodies}

The classification of the kinds of bodies may be accomplished in different ways. The most important kinds of bodies include the division into: a) monocratic and collegial bodies, b) chief and lower level bodies, c) central and local bodies, d) central government and self-government bodies, e) decisive and consultative-advisory bodies, f) professional and professional-social, social bodies, g) united and non-united administrative bodies, $\mathrm{h}$ ) elected, appointed, nominated bodies and created with the force of law, i) specialized and general bodies ${ }^{15}$.

In the case of 'nature conservation bodies' the legislator applies most of the solutions. The model decisive body is especially characteristic (it is monocratic and professional at the same time), besides which a consultative-advisory body (collegial and most often professional-social) is appointed. Moreover, as already mentioned before, the principle of public authority decentralization results in the fact that among the nature conservation bodies there are both central government administrative bodies and self-government administrative bodies.

14 For an overview of Polish Nature conservation law in this regard - see: Prawo o ochronie przyrody: komentarz, ed. J. Sommer, Wrocław 2001; Polskie prawo ochrony przyrody, ed. J.Ciechanowicz-McLean, Warszawa 2006; Teoretyczne podstawy prawa ochrony przyrody, ed. W. Radecki, Wrocław 2006; Prawo ochrony przyrody: stan obecny, problemy, perspektywy, ed. D. Kopeć and N. Ratajczyk, Łódź 2008; B. Rakoczy, Prawo ochrony przyrody, Warszawa 2009; W. Radecki, Prawna ochrona przyrody w Polsce, Czechach i Stowacji: studium prawnoporównawcze, Warszawa 2010; W. Radecki, Ustawa o ochronie przyrody: komentarz, Warszawa 2012; K. Gruszecki, Ustawa o ochronie przyrody: komentarz, Warszawa 2013; Prawo ochrony różnorodności biologicznej, ed. M. Górski, J. Miłkowska-Rębowska, Warszawa 2013.

15 See: J. Zimmermann, Prawo administracyjne, Zakamycze 2006, p. 98-108; Prawo administracyjne. Pojęcia, instytucje, zasady w teorii i orzecznictwie, ed. by M. Stahl, Warszawa 2013, p. 269-274; J. Boć, Zatożenie badawcze struktur administracji publicznej, in: Koncepcja systemu prawa administracyjnego, ed. J. Zimmermann, Warszawa 2007, p. 181-193. 
A fuller review of solutions applied by the legislator in reference to nature conservation administration is possible to obtain by combining the kinds of bodies with the categories of tasks, which are included in nature conservation as defined by the act. From the functional point of view, environmental protection (as well as nature) is accomplished by: a) organization tasks, b) rationing-obliging tasks, c) monitoring-supervisory tasks, d) executive tasks ${ }^{16}$. The review of solutions applied by the legislator allows to distinguish three fundamental groups of 'nature conservation bodies'. It should be pointed out that the analysis concerns decisive bodies. The scope of competence of a consultative-advisory body is in principle limited by the tasks of decisive body, beside which is has been established. It should be also added that the classification has a general, vague and cross character, because specific provisions provide for exceptions giving bodies specific characteristics.

The first group includes those, which accomplish above all rationingobliging tasks within nature conservation, very often combined with monitoring-supervisory tasks. Whereas the bodies from the second group are those which were primarily appointed to accomplish executive tasks, usually combined with organization tasks. The third group consists of bodies accomplishing above all monitoring-supervisory tasks, usually combining them with organization tasks.

The first group includes environmental protection bodies from the catalogue included in article 91 of the NCA (the Minister competent for the environment, the General Director for Environmental Protection, voivode, the regional director for environmental protection, the marshal of a voivodeship, the director of a national park, starost, wojt, town or city mayor), which should be extended to self-government bodies ${ }^{17}$. Gmina council and voivodeship sejmik have unambiguous competences of this kind indicated in the Act on Nature Conservation, however, powiat council have indirect competences (e.g. tasks to assure the best acoustic state of environment on the grounds of the provisions of the EPA). It should be also indicated that both kinds of tasks in this group are accomplished

16 See: M. Król, Podmiotowy zakres regulacji - organizacja ochrony przyrody, in: Prawo ochrony środowiska, ed. M. Górski, Warszawa 2014, p. 524-529; W. Radecki, Organizacja ochrony środowiska, in: Instytucje prawa ochrony śodowiska: geneza, rozwój, perspektywy, ed. W. Radecki, Warszawa 2010, p. 154-163.

17 Further referred to as LGU. 


\section{Karolina Karpus}

by monocratic bodies as a rule. Whereas, collegial bodies accomplish main rationing-obliging tasks.

In the second group of 'nature conservation bodies' the bodies should be included, which accomplish the conservative function of environmental protection in the strict meaning of the term. One may indicate here the director of $\mathrm{s}$ national park and forest administrative bodies, i.e.: the General Director of the State Forests, a director of regional directorate of national forests and a forest division manager. Taking into account the fact that the regional directorate for environmental protection is among others responsible for nature reserves and species protection, it is possible to include this body into the discussed group. A similar situation has place in the case of the General Directorate for Environmental Protection (Nature 2000, species protection, ex situ protection). Taking into account the fact that objective forms of nature conservation such as green areas protection and afforestation are the tasks of gmina self-government bodies, they should be also included in this group. In the current legal state, the director of a landscape park (the group of the parks) is not listed in the catalogue included in article 91 of the NCA. Nevertheless, it seems that there are grounds to accept (based on appropriate interpretation) that the director of a landscape park has authority to some extent, which is necessary to accomplish executive and organization tasks. This fact allows to include the director of a landscape park into the group of 'nature conservation bodies'.

In the third group of 'nature conservation bodies' the Inspectorate of Environmental Protection bodies should be included. The example of monitoring-supervisory authority of the voivodeship inspector of environmental protection is article 19 of the Act of 20 July 1991 on Environmental Protection Inspection ${ }^{18}$, according to which in the proceedings on the decision on zoning approval concerning the undertaking which may have a significant impact on the environment the voivodeship inspector of environmental protection has rights of the party in administrative proceedings and in the proceedings before administrative court if they report their presence in such proceedings. As an example, one may indicate the tasks resulting from the Act of 2001 on Genetically Modified Organisms. In reference to organization tasks one may indicate

18 Journal of Laws of 2013, item 686 with amendments, consolidated text. 
the system, coordinated by the Inspectorate of Environmental Protection, which is the national environmental monitoring, as well as the obligations connected with register keeping (e.g. the register of direct damage risk and damage to the environment).

Outside the division of 'nature conservation bodies' based on the criterion of accomplished tasks, it is also possible to make assessments from the subjective point of view, referring to internal branches of environmental protection law. In order to do it the following areas must be defined:

- nature conservation in situ (areal nature conservation, Nature 2000, objective nature conservation, species nature conservation, forests, wild game protection);

- nature conservation ex situ (botanical and zoological gardens, animal rehabilitation centres, trade in endangered plants and animals);

- research and observation of the state of the natural environment;

- green and afforestation areas conservation;

- genetically modified organisms;

- landscape protection;

- spinal animals protection;

- environmental damage and its remediation;

- environmental impact assessment.

Taking into account the size of the article, it is not possible to review in detail the solutions applied by the legislator in this scope in individual sources of nature conservation law. However, the negative phenomenon of 'competence dispersion' by the legislator might be noticed in a situation when a task is assigned to several bodies although there are already specialized nature conservation bodies in a given area. This negative phenomenon might be illustrated with article 75 of the Act of 2008 on Access to Information on Environment and its Protection, Public Participation in Environmental Protection and on Environmental Impact Assessment in the context of environmental impact assessment. In the case of only one task, i.e. the issue of decision on environmental conditions, the legislator found it necessary to give competence to five nature conservation bodies, i.e.: the General Directorate for Environmental Protection, the regional director for environmental protection, starost, the director of the regional directorate of State Forests and wojt (town or city mayor). A similar example is a legal solution concerning the establishment and management of nature conservation forms, in reference to which both central government administrative bodies (specialized and general; chief, central and local) and 
self-government bodies were indicated, and taking into account the change of the national park establishment method - currently also legislative bodies. Additionally, in the case of Nature 2000 areas the cooperation of Polish bodies with the European Commission is realized ${ }^{19}$. The initial enumeration already shows the level of complexity of the nature conservation structure established by the legislator.

To sum up, the above presentation of the kinds of nature conservation bodies along with the outline of their competences might lead to the following conclusions. Firstly, the nature conservation administration consists currently of a considerable (and still growing - see: the establishment of the General Directorate for Environmental Protection and the regional directorate for environmental protection in 2008) group of public administrative bodies and an equally big group of other administrative entities. Secondly, the legislator forming the administration of nature conservation does not use sufficiently the competences of specialized bodies. The principle of decentralisation of public administration has a fundamental significance. However, it does not mean that any possible transfer of competences within nature conservation to local self-government bodies has reflection in reality. Thirdly, the phenomenon of 'competence dispersion' of nature conservation bodies must be assessed negatively, because without doubt it impairs the efficiency of the accomplishment of that public task.

\subsection{The characteristic of chosen specialized nature conservation bodies in Poland}

As mentioned above, nature conservation bodies, which accomplish tasks of different character within broadly defined nature conservation, are numerous and diversified on account of their organization. Because of the limited scope of this article, the presentation of specific Polish nature conservation bodies will be limited to specialized bodies, i.e. those, whose principal task is nature conservation. Consequently, local self-government

19 For an overview of the law of the Natura 2000 - see: A. Habuda, Obszary Natura 2000 w prawie polskim, Warszawa 2013; A. Habuda, Ochrona przyrody a dziatalność gospodarcza na obszarach Natura 2000, in: Gospodarcze prawo środowiska, ed. J. Ciechanowicz-McLean and T. Bojar-Fijałkowski, Gdańsk 2009; Problemy wdrażania systemu Natura 2000 w Polsce, ed. A. Kaźmierska-Patrzyczna, M. A. Król, Poznań 2013. 
bodies will be excluded from research. Such a decision might be justified by the fact that self-government system in Poland is a separate and extensive issue on one hand and it is not possible to include it in this article. On the other hand, self-government bodies cannot be classified as 'specialized nature conservation bodies' on account of the fact that the Polish legislator assigned them to the task of nature conservation (or more broadly - environmental protection) as one of many tasks of public administration.

\subsubsection{Directors for Environmental Protection}

The Directors for Environmental Protection are new specialized nature protection bodies, established by the Polish legislator by the Act of 3 October 2008 on Access to Information on Environment and its Protection, Public Participation in Environmental Protection and on Environmental Impact Assessment. The legislator appointed these new bodies in a particular way. From the technical point of view, this solution should be associated with gradual changes in the Polish environmental protection law, which began at the beginning of $21^{\text {st }}$ century and concern the competences of a local government body, i.e. a voivode. In the previous legal state (before the Act of 2004 on Nature Conservation) the voivode was a body accomplishing multiple tasks within nature conservation (e.g. established nature reserves on the way of a local law act). However, in the last decade, the Polish legislator gradually limited voivode's competences within nature protection, transferring them above all to self-government bodies (according to the principle of public administration decentralisation).

Suddenly, in the middle of 2008, the Polish legislator changed their previous method of conduct within this area - and instead of continuing to transfer voivode's competences to self-government bodies - appointed a new group of government administrative bodies, i.e. the directors for environmental protection. From the technical point of view, the group of current employees of a voivodeship office, employed in departments dealing with nature protection, was transferred to offices, appointed to serve new bodies - respectively to 16 regional directorates for environmental protection (with the offices in voivodeship capitals). At the central level, the situation looked alike, but here it concerned the employees of the Ministry of the Environment, who were transferred to work in a new office - the General Directorate for Environmental Protection in Warsaw. 


\section{Karolina Karpus}

According to the new Act of 2008, the new group of specialized nature protection bodies includes:

- central government administrative body, i.e. the General Director for Environmental Protection (appointed by the President of the Council of Minsters out of persons selected in open and competitive recruitment process, on the motion of the Minister competent for environmental protection - article 126 section 1 of the Act of 2008);

- local government administrative bodies in voivodeships, i.e. 16 regional directors for environmental protection (appointed by the the General Director for Environmental Protection - article 130 section 1 of the Act of 2008).

These bodies are monocratic, permanent and professional and they are come under the authority of the minister competent for environmental protection.

According to article 127 section 1 of the Act of 2008, the tasks of the General Director for Environmental Protection are as follows: 1) the participation in environmental protection policy within nature conservation and investment process supervision; 2) the supervision of responsibility for environmental damage prevention and environmental damage remediation; 3) the collection of data and compilation of information on Nature 2000 network and other protected areas and on environmental impact assessment; 4) the cooperation with the competent environmental protection bodies in other countries and with international organizations and the European Commission; 5) the cooperation with the Chief Nature Conservator and the National Nature Conservation Council in matters concerning nature conservation; 6) the cooperation with local self-government bodies in matters concerning environmental impact assessment and nature conservation; 7) the participation in strategic environmental impact assessments; 8) the participation in proceedings in the matter of transborder environmental impact; 9) the accomplishment of tasks connected with Nature 2000 network, which are defined in the Act of 16 April 2004 on Nature Conservation; 10) the accomplishment of tasks connected with the participation of organizations in ecomanagement and audit scheme (EMAS) in accordance with the principles and within the scope defined in the Act of 15 July 2011 on National Eco-Management and Audit Scheme (EMAS); 11) the cooperation with ecological organizations. Whereas, according to article 131 section 1 of the Act of 2008, regional directors for environmental protection have 
following tasks: 1) the participation in strategic environmental impact assessments; 2) the assessment of environmental impact of undertakings or the participation in those assessments; 3 ) the formation and liquidation of nature conservation forms on the grounds of the Act of 16 April of 2004 on Nature Conservation; 4) the protection and management of Nature 2000 areas and other forms of nature conservation, on principles and in the scope defined in the Act of 16 April 2004 on Nature Conservation; 5) the issue of decisions on the grounds of the NCA; 6) the conduct of proceedings and the accomplishment of other tasks mentioned in the Act of 13 April 2007 on environmental damage prevention and its remediation; 7) the transmission of data to the base mentioned in article 128 ; 8) the cooperation with selfgovernment bodies in matters of environmental impact assessment and nature conservation; 9) the cooperation with ecological organizations; 10) the accomplishment of tasks, including the issue of decisions and the commission of expertise within waste management.

\subsubsection{Area forms of nature conservation bodies}

In the Polish nature conservation law, the legislator uses the expression 'nature conservation form'. The notion 'nature conservation form' should be understood as a group of legal norms regulating the protection of chosen elements of animate and inanimate nature, in other words - a group of legal norms including chosen elements of nature with special legal administrative regime (bans and orders). The Polish legislator classifies three forms of nature conservation (article 6 section 1 of the NCA):

a) area forms of nature conservation: national parks, nature reserves, landscape parks and protected landscape areas;

b) object forms of nature conservation: natural features of historic importance, documentary stands, ecological lands, natural-landscape complexes;

c) species protection forms: species protection of plants, animals and mushrooms.

The above mentioned forms of nature conservation have 'domestic' character of legal regimes, which are accompanied by nature conservation norms resulting from the EU law, i.e. Nature 2000 areas.

From the point of view of the subject matter of this article, it should be pointed out that only in the case of two above mentioned forms of nature 
protection, the Polish legislator provided for independent administrative structure. These are two area forms of nature conservation, i.e. national park and landscape park. The bodies managing those forms of nature conservation are their directors - respectively: the director of a national park and the director of a landscape park.

The national park is the most specialized form of nature conservation in Poland, constituting a sort of a special zone. According to article 8 section 1 of the NCA, the national park covers the area not smaller than 1000 ha with distinctive natural, scientific, social, cultural and educational values, on which all nature and landscape qualities are under protection. Whereas, according to article 8 section 2, a national park is established in order to preserve biological diversity, resources, creations and ingredients of inanimate nature and landscape values, to preserve the right state of resources and ingredients of nature and to reconstruct the deformed natural habitats, plants habitats, animal habitats or mushroom habitats. Around national parks there is an obligatory buffer zone.

Each national park (there are currently 23 parks in Poland) has its own administration, which consists of:

- the director of a national park, appointed by the Minister competent for environmental matters, selected out of the persons in open and competitive recruitment (article 8c section 1 of the NCA);

- the National Park Service, including the National Park Guard.

The director of a national park has a status of 'nature conservation body' (article 91 section 2c of the NCA), who manages the national park activities and represents the national park outside (article $8 \mathrm{~d}$ of the NCA).

According to article 103 section 1 of the NCA, the National Park Services accomplish tasks in the field of nature conservation, scientific research and educational activities and also in the field of national park property guard and crime and offences combat within nature conservation on the territory of a national park. At the same time, the latter group of tasks is accomplished by the officers of the National Park Guard, being the part of these Services (article 108 section 1 of the NCA).

A landscape park constitutes a smaller area form of nature conservation in Poland in comparison to a national park. According to article 16 section 1 of the NCA, a landscape park covers an area protected on account of its natural, historic and cultural values and landscape values in order to maintain and promote those values in sustainable development conditions. Currently a landscape park established in the way of a resolution of the voivodeship 
sejmik, being an act of local law. On the areas bordering the park the buffer zone is determined optionally.

Each landscape park (there are currently 122 of them on the territory of Poland ${ }^{20}$ ) has its own administration, which consists of:

- the director of a landscape park, appointed by the voivodeship management after consulting the regional nature conservation council (article 105 section 2 of the NCA);

- the Landscape Park Services accomplishing on the territory of a park tasks within nature conservation, landscape values, historic and cultural values and educational activities (article 107 section 1 of the NCA).

According to article 105 section 4 of the NCA, the director of a landscape park is responsible for: 1) nature protection, landscape values, historic and cultural values; 2) organization of educational, tourist and recreational activities; 3) participation in the scope of nature conservation with organizational units and legal and natural persons; 4) submission of notions to local zoning plans concerning zoning of areas enclosed in landscape parks. The Polish legislator allowed the possibility to form the groups of landscape parks. In such a case, the body managing the group is called the director of a landscape park group and has generally the same competences.

In the last decade, a landscape park as a form of nature conservation, constituted the subject of analysis of the Polish legislator, which introduced several changes in the scope. At the time of the implementation of the current Act on Nature Conservation in power - i.e. the Act of 2004 - landscape parks were under the authority of a voivode as part of local government administration. A radical change took place on 2 August 200921, when the Polish legislator transferred landscape parks to competences of voivodeship self-government bodies, changing at the same time the method of the appointment of the director of a park and the whole administrative structure. Currently, landscape parks are classified as part of self-government and not government administration.

20 Current state according to data of the Central Register of Nature Protection forms, kept by the General Directorate for Environmental Protection: http://crfop.gdos.gov.p1/ CRFOP

21 According to article 21 point 1 of the Act of 23 January 2009 on changes of some acts on account of the changes in organization and division of public administration tasks in voivodeship, Journal of Laws of 2009, No 92, item 753 with amendments. 


\subsubsection{Forest administration}

In the Polish nature conservation law, ecosystems are classified from the nature point of view as 'forests' undergoing special legal regime. As defined by the law, 'forest' is 'land':

1) 'of a compact area of at least of $0.10 \mathrm{ha}$, covered with forest plants (forest crops) - trees, shrubs and fruits of the forest - or temporary void of it: a) intended for forest production or b) constituting nature reserve or being a part of a national park or c) entered into the register of natural monuments;

2) related to forest management and used for the needs of forest management: buildings and constructions, water drainage and irrigation systems, spatial division lines of a forest, forest roads, grounds under power lines, forest nurseries, wood storage places and areas used for forest car parks and tourist utilities ${ }^{22}$.

In the light of the Polish law, the owners of forests may be private and public entities. In the latter case the following forests must be distinguished, i.e. the forests being the property of the State Treasury, which are as a rule managed by a distinguished structure of public administration - the State Forests National Forest Holding ${ }^{23}$.

According to article 32 section 1 of the Act on Forests, the State Forests hold a formal status of a national organization unit without legal personality, representing the State Treasury within the scope of managed property (forests). The structure of the State Forests has been adapted to the specificity of special grounds, i.e. forests being the property of the State Treasury, based on the special division of the whole country, which is not coherent with the units of fundamental division of the state (voivodeship, powiat, gmina). The structure of forest administration looks as follows:

a) at the central level - the General Director of State Forests (appointed by the Minister competent for environmental matter - article 133 section 2 of the Act on Forests);

b) at the local level:

- 17 organization units of higher level (regional directorates of the State Forests), managed by regional directors of the State Forests

Article 3 of the Act of 28 September 1991 on Forests.

23 Further referred to as, State Forests'. 
Directorate (appointed by the General Director of the State Forests - article 33 section 3 point $9 \mathrm{c}$ of the Act on Forests);

- circa 430 units of lower level (forest division offices), managed by forest division managers (appointed by regional directors of the State Forests Directorate having jurisdiction over a given area article 34 point $2 \mathrm{~b}$ of the Act on Forests);

- other local organization units (forest circles and forest districts);

- other organization units of the State Forests within the national and local range (national range units ${ }^{24}$, regional range units ${ }^{25}$ ).

It should be also added that in the personal aspect, the structure of the State Forests embraces employees of Forest Services, who deal with: 1) management matters of forest being in the jurisdiction of the State Forests; 2) forest management and forest protection; 3 ) crime and offences combat within the scope of forest damage and nature conservation and other tasks within the scope of property protection; 4) supervision matters, which are defined in article 5, in case such supervision is exercised (article 45 section 1 of the Act on Forests).

The special character of public administration structure of the State Forests makes it difficult to explicitly mark out nature conservation bodies acting in this structure. Generally, it seems that without big doubts three cases may be indicated here: the General Director of the State Forests, a regional director of the Directorate of the State Forests and a forest division officer, all of them having authority within the tasks, included in the above determined notion 'nature conservation'.

\section{The efficiency of actions of nature conservation bodies}

The efficiency assessment of actions of public administrative bodies constitutes a task going beyond the strictly legal field. From a legal perspective, the assessment may be carried out mainly by analysis of judicature concerning the disputes on jurisdiction between nature conservation bodies (both negative and positive; between local self-government units; between government administrative units, and the combination of both) on one

24 E.g. Kostrzyca Forest Gene Bank.

25 E.g. Forest Transportation Centre in Gorzów Wielkopolski. 


\section{Karolina Karpus}

hand, on the other hand - the institution of agreement between public administrative bodies. To illustrate both issues it is sufficient to refer to the main act for this part of environmental protection law, which is nature conservation - thus to the Act of 2004 on Nature Conservation.

In reference to the Act of 2004 on Nature Conservation, the first matter which should be pointed out is the issue of permits to remove trees and shrubs. As a rule, the body competent in this matter is wojt, town or city mayor. However, according to article 90 in fine of the NCA, in reference to real estates owned by gmina, a competent body to issue a permit is starost. To illustrate this matter, one may refer to the resolution of the Supreme Administrative Court of 10 September 2013, sign. II OW 66/1326, settling the dispute between those bodies in the case, when the motion to issue a permit was submitted by the entity being a perpetual lessee of land belonging to gmina, and not directly gmina. In the resolution, the court pointed out the jurisdiction of starost, which was justified as follows: 'it arises from the case files that the plot No [...] in C., from which a tree was to be removed, is the property of Gmina C., whereas the Housing Community $[\ldots]$ is a perpetual lessee of the estate. Thus, according to article 90 of the NCA, the body competent to approve the motion is starost. The circumstance pointed out by the Starost of C., that the motion to issue a permit to remove a tree is submitted by the Housing Community, being a perpetual lessee of the property, has no significance for indicating a body competent in this matter. According to article 232 of the Civil Code, gmina is still the owner of the ground'.

The competence dispute concerning the jurisdiction to issue permits to remove trees and shrubs is also possible at another level - the combination of both nature conservation and natural monuments protection. According to article 83 section 2 of the NCA, the permit to remove trees or shrubs from the property entered into the register of monuments is issued by the voivodeship conservation officer. Doubts leading to competence disputes are the result of the interpretation of an expression 'entry into the register of monuments' of permit subject - trees or shrubs. To illustrate this problem, the stand of the Supreme Administrative Court may be useful. The Court stated in this matter, that: 'pursuant to article 83 section 2 of the NCA, the voivodeship conservation officer would have the competence to issue

26 Published in the Central Base of the Resolutions of Administrative Courts: http:// orzeczenia.nsa.gov.pl, further referred to CBOSA. 
a permit to remove trees or shrubs growing in the area of urban arrangement entered into the register of monuments if in the decision to enter a given urban arrangement into the register, the greenery had been listed as subject to legal protection. Moreover, the conservation officer would have the competence to examine the issue if the trees in the motion grew on the grounds entered individually into the register of monuments. Whereas, in the examined issue, the trees motioned to be removed grew on the grounds within the urban arrangement of the town centre of P. entered into the register of monuments, nevertheless, they have the character of modern housing estate greenery, which is the element of land development next to blocks of flats'. ${ }^{27}$

The other source of competence disputes may be the combinations of two acts - the Environmental Protection Act and Nature Conservation Act - in the aspect of concerning liability for damages on account of the limitation of subjective rights because of the conservation of environmental elements. A body competent to recognize an area as a nature reserve (and to define its buffer zone) is according to article 13 section 3 of the NCA the regional directorate for environmental protection. Whereas, according to article 130 section 1 point 1 of the EPA, the limitation of the mode of usage of the estate on account of environmental resources protection may take place by taking under protection areas or objects on the grounds of the provisions of the NCA - including the establishment of a nature reserve. According to article 131 section 1 of the EPA, the body competent to define, on the way of a decision, the amount of compensation because of the limitation of the mode of usage of the estate is the starost. In the case settled by the resolution of the Supreme Administrative Court of 7 December 2010 , sign. II OW $72 / 10^{28}$ the subject of the analysis was a competence dispute between the regional directorate for environmental protection and starost within the scope of compensation payment for the flooding of grassland situated between the borders of a nature reserve and its buffer zone. The dispute was settled by means of indicating starost as a competent body, which was justified by the Supreme Administrative Court, accepting the interpretation of the objectives of the article 130 section 1 point 1 of the EPA on account of article 131 section 1 of the EPA, according to

27 The resolution of the Supreme Administrative Court of 20 July 2012, II OW 82/12, CBOSA.

28 Published in CBOSA. 


\section{Karolina Karpus}

which " the submission of an area for protection (...) on the grounds of the provision of the NCA « also embraces the buffer zone of a nature reserve, i.e. a special area of ecological character, which according to article 5 point 14 of the NCA is subject to legal protection. For, it is a protection zone bordering in this case with a nature reserve and formed only for a given legal nature conservation form in order to its prevention from outer threats, which are result of human activities. [...] It means that there are no legal basis to recognize ratio legis the legislator within the scope of application of a separate competence norm to rule in this case by the regional director for environmental protection in Olsztyn if, according to article 130 section 1 point 1 , the legislator had already given the competence to starost competent in this field regarding the area of a nature reserve, whereas its buffer zone is regulated by article 5 point 14 on account of article 13 section 2 and 3 of the NCA'.

The second important issue, occurring in the judicature of administrative courts, casting light on the question of nature conservation bodies' efficiency, is the problem of legal institution, which are the arrangements - most often between a general body, conducting the proceedings and specialized bodies of nature conservation administration.

Once again, the issue of a permit to remove trees and shrubs may be indicated here. According to article 83 section 2a of the NCA, a permit to remove trees in the area of land take of public road, excluding foreign poplar species, is issued after the consultation with the regional directorate for environmental protection, and according to article 83 section $2 \mathrm{~b}$ if the stand is not expressed within 30 days from the day of receiving the project of the permit by the regional directorate for environmental protection, it is recognized as the issue of permit. The potential difficulties in reference to making arrangements are concisely illustrated by the judgement of the Voivodeship Administrative Court in Warsaw of 13 December 2013, sign. IV SA/Wa 2083/13 ${ }^{29}$, in which the court firstly examined the way of using by the regional directorate for environmental protection authority to conduct explanatory proceedings within the arrangement, and secondly - the court interpreted the provision on the deadline of its accomplishment. In this case, the Voivodeship Administrative court indicated that: 'another project of a decision permitting to remove those two trees along with

\footnotetext{
29 Published in CBOSA.
} 
the letter from the Wojt of Gmina (...), which included the request for the arrangement, was received by the regional directorate for environmental protection on (...) July 2012. Thus, the Directorate was to issue its decision by the end of August 2012. It was also obliged to conduct explanatory proceedings in the scope allowed by article $50 \S 1$ of the Administrative Proceedings Code. At the same time, in the case of not submitting by the wojt demanded and essential information in this scope, the regional directorate for environmental protection was entitled to reject the arrangement of the submitted permit project. [...] During explanatory proceedings conducted by the body within article $50 \S 1$ of the Administrative Proceedings Code, the suggestion of the necessity of significant supplementation of the arranged project of the permissive decision (point 4 of the summons) was not included. The introduced changes to the project eventually led to the refusal of the arrangement. Thus, it can not be assumed that the 30 -days period has commenced the course since the date of the sending the supplemented project of the permissive decision by the wojt.

One may have the impression that the first instance body [the regional directorate for environmental protection] (examining the wojt's motion and decision project in this field not for the first time), turned to the wojt to supplement the submitted documentation and permit project, directly indicating to the defectiveness of the submitted project in order to obtain the possibility of counting a new 30-day-period. Of great importance is the fact of a previously mentioned refusal of the arrangement project of such permit by the regional directorate for environmental protection. Justifying its rejection, the body was obliged to indicate all necessary documents and arrangements from the main body in order to enable to submit another project of permissive decision fulfilling expected requirements'.

Another example may be the arrangement of a bill concerning the change of borders of a landscape park. The unusual solution to this problem may be shown by the example of the resolution of the Supreme Administrative Court of 20 December 2012, sign. II OSK 2795/12, rejecting the complaint in cassation of an individual entity, who by means of a complaint about the voivodeship's marshal failure to act in the scope of the arrangement of a landscape park's borders tried to lead to expected action. In this case, the Supreme Administrative Court reminded that according to article 16 section 4 of the NCA, the voivodeship sejmik passes the resolution concerning the establishment, change of borders or liquidation of a landscape park after the arrangement of the bill with a competent 


\section{Karolina Karpus}

gmina council and a competent regional director for environmental protection. The essence of the accepted solution is that the establishment, change of borders or liquidation of a landscape park comes on the way of a local law act after the arrangement of a bill of the voivodeship's sejmik in this scope with a competent gmina council. The provision, however, does not apply to the obligation to take action in an individual case, whose not taking could be a ground for making a complaint about failure to act, which is defined in article $3 \$ 2$ point 8 of the Act - Law on Proceedings before Administrative Courts. Thus, a complaint about the voivodeship marshal's failure to act within the scope of the arrangement of a bill concerning the establishment, change of borders or liquidation of a landscape park was justly rejected, because article $3 \$ 2$ point 8 of the Act - Law on Proceedings before Administrative Court cannot be the ground for ordering the body to arrange a bill concerning the change of borders of a landscape park'.

One should also indicate the resolution of the Supreme Administrative Court in Warsaw of 10 July 2007, sign. II OSK 526/0730, which was passed in accordance with the law state no longer binding, however, it has its value concerning the substance. The resolution concerns article 16 section 3 the second sentence of the NCA, according to which currently the liquidation or the decrease of a landscape park area occurs by way of a resolution of the voivodeship sejmik, after the arrangements with area competent gmina councils, because of the irretrievable loss of natural, historical and cultural values as well as landscape qualities on the grounds projected to be excluded from protection. Previously, it happened by way of the order of a voivode with the same content. In this case, the subject of analyses was the order of a voivod toughening bans on the area of an already existing landscape park.

In its stand on the case, the Supreme Administrative Court indicated that the provisions of article 16 section 3 of the NCA state 'three categories of acts of local law, mainly orders [currently - resolutions] concerning the establishment, change of borders or liquidation of a landscape park. The resolution concerning the formation aims to enact, organize, form or in other words constitute a new form. It appears that the resolution concerning the formation results in the establishment of a new factual state, i.e. the formation of a new landscape park. In the meantime, the Welski Lanscape Park, as mentioned before, has been functioning on the territory

\footnotetext{
30 Published in CBOSA.
} 
of Warmian-Masurian voivodeship since 1995. Moreover, the resolution of 27 September 2005 [concerning the Welski Landscape Park, on the grounds of article 16 section 3 of the NCA defining the area and conservation objectives of the Park and introducing bans in force on its territory], does not comprise in the category of orders concerning the change of borders. As the name suggests, the change of borders requires some modifications concerning the functioning of the park, the increase of decrease of a park area. Moreover, for obvious reasons, the order questioned in the complaint, does not comprise in the group of acts concerning the liquidation of a landscape park. (...) According to the Supreme Administrative Court, the obligation of the arrangement of a bill only refers to acts, whose aim is the establishment, change of borders or liquidation of a landscape park, because only such actions are significant for gminas, influencing their authority. For example, the establishment of a landscape park limits gmina's autonomy within the scope of spacial planning on the territory of a park. The change of legal restrictions in force, which had place in the factual state of the case, on the territory of a given park does not have such results. (...) According to the statement that the order of the Warmian-Masurian Voivode of 27 September 2005 is not an order concerning the establishment or change of borders of a landscape park, one may acknowledge that the bill of the order did not require the arrangement procedure'.

Thus laconic review of administrative courts' resolutions passed on the grounds of only one main act - the Act of 2004 on Nature Conservation, is a sufficient reason to formulate negative opinion on two fundamental issues. One of them is mentioned before 'competence dispersion' between nature conservation bodies, like between those bodies and other public administrative bodies in one specific case. The second issue - on the background of the institution of arrangement - is the simulation of independence of general nature conservation bodies by the legislator (i.e. those which apart from nature conservation/environmental protection accomplish several other administrative tasks - especially local selfgovernment bodies) in the relation with specialized nature conservation bodies (appointed mainly and exclusively to accomplish this public task). 


\section{Karolina Karpus}

\section{Summary}

Establishing nature conservation law over the last decade, it seems that the legislator acted in many cases on a short-term basis, not always consistently. In the doctrine of environmental protection law, there has been a long discussion concerning the organization of environmental protection administration (i.e. also nature conservation administration) in Poland. One should concur with the argument on the necessity of consolidation of those structures, with the emphasis on maintaining their specialized character (among others the suggestion concerning the formation of the Polish Environmental Agency ${ }^{31}$ ). It means that the role of self-government bodies in the scope of those tasks must be rethought. In the doctrine, the doubts are praised concerning the legitimacy of assigning rationing-obliging tasks to self-government bodies within nature conservation (the conflict of interest, nature as a rule is public national good). The construction of a new organization model of environmental protection in Poland will require in the first place the development of values and protection objectives of this resource and consequently legal solutions.

The above mentioned issues concern, however, the question of environmental protection organization in a long perspective. In a shorter perspective, more simple postulates de lege ferenda concerning directly the organization of nature conservation administration should be formulated. The first may be the postulate to withdraw by the legislator from introducing catalogues of bodies and institutions into environmental acts, suggesting in the content their closed character - when in fact it does not correspond with the reality. One may also repeat the suggestion of using the action possibilities of already existing specialized bodies of government administration in the place of current solutions concerning general bodies, i.e. self-government bodies. However, in many cases the independence of general bodies competent to issue an act is strongly limited by the legislator within the scope of the extensive model of arrangements with specialized bodies. Once more, attention should be paid to the issue of 'competence dispersion' between nature conservation bodies, as a phenomenon, which

31 M. Rudnicki, Koncepcja reformy stużb ochrony środowiska, in: Organizacja ochrony środowiska, ed. M. Rudnicki, Lublin 2011, p. 135-146. 
should be obviated in the near future, because it does not serve the nature conservation interest.

\section{Bibliography}

Administracja publiczna a ochrona przyrody: zagadnienia ekonomiczne, społeczne oraz prawne, ed. M. Górski, Warszawa-Stare Babice-Siedlce 2012.

Boć J., Zatożenie badawcze struktur administracji publicznej, in: Koncepcja systemu prawa administracyjnego, ed. J. Zimmermann, Warszawa 2007.

Górski M., Ochrona środowiska jako zadanie administracji publicznej, Łódź 1992. Gruszecki K., Ustawa o ochronie przyrody. Komentarz, Warszawa 2013.

Habuda A., Obszary Natura 2000 w prawie polskim, Warszawa 2013.

Habuda A., Ochrona przyrody a dziatalność gospodarcza na obszarach Natura 2000, in: Gospodarcze prawo środowiska, ed. J. Ciechanowicz-McLean and T. BojarFijałkowski, Gdańsk 2009.

Instytucje prawa ochrony środowiska: geneza, rozwój, perspektywy, ed. W. Radecki, Warszawa 2010.

Integralna ochrona przyrody, ed. M. Grzegorczyk, 2007.

M. Król, Podmiotowy zakres regulacji - organizacja ochrony przyrody, in: Prawo ochrony środowiska, ed. M. Górski, Warszawa 2014.

Ocena modelu prawnego organizacji ochrony środowiska w Polsce i na Stowacji: praca zbiorowa, ed. E. Ura, J. Stelmasiak, S. Pieprzny, Rzeszów 2012.

Ochrona przyrody, ed. M. Gwiazdowicz, Studia BAS No 10, Warszawa 2008.

Organizacja ochrony środowiska, ed. M. Rudnicki, Lublin 2011.

Polskie prawo ochrony przyrody, ed. J.Ciechanowicz-McLean, Warszawa 2006.

Prawo administracyjne. Pojęcia, instytucje, zasady w teorii i orzecznictwie, ed. M. Stahl, Warszawa 2013.

Prawo o ochronie przyrody: komentarz, ed. J. Sommer, Wrocław 2001.

Prawo ochrony przyrody: stan obecny, problemy, perspektywy, ed. D. Kopeć and N. Ratajczyk, Łódź 2008.

Prawo ocbrony różnorodności biologicznej, ed. M. Górski, J. Miłkowska-Rębowska, Warszawa 2013.

Problemy wdrażania systemu Natura 2000 w Polsce, ed. A. KaźmierskaPatrzyczna, M. A. Król, Poznań 2013.

Przyborowska-Klimczak A., Ochrona przyrody. Studium prawnomiędzynarodowe, Lublin 2004.

Radecki W., Organizacja ochrony środowiska, in: Instytucje prawa ochrony środowiska: geneza, rozwój, perspektywy, ed. W. Radecki, Warszawa 2010. 


\section{Karolina Karpus}

Radecki W., Prawna ochrona przyrody w Polsce, Czechach i Słowacji: studium prawnoporównawcze, Warszawa 2010.

Radecki W., Ustawa o ochronie przyrody. Komentarz, Warszawa 2012.

Rakoczy B., Prawo ochrony przyrody, Warszawa 2009.

Rudnicki M., Koncepcja reformy stużb ochrony środowiska, in: Organizacja ochrony środowiska, ed. M. Rudnicki, Lublin 2011.

Symonides E., Ochrona przyrody, Warszawa 2008.

Teoretyczne podstawy prawa ochrony przyrody, ed. W. Radecki, Wrocław 2006.

Zimmermann J., Prawo administracyjne, Zakamycze 2006.

\section{Email}

kkarpus@law.umk.pl 